\title{
Soil water behaviors and their effects on river runoffs: The Saromabetsu River basin, Hokkaido
}

\author{
Mohammad T. ISLAM*1, Kazuhisa A. CHIKITA*2, \\ Tomoyuki WADA*2 and Takuma YAMAGUCHI*1
}

\begin{abstract}
The soil water behaviors during rainfall or snowmelt events were explored by monitoring the soil moisture on the slope of forest and grassland in the Saromabetsu river basin, Hokkaido, in the summer season of 2008 and the snowmelt season of 2009 . The river basin is covered mostly by forest ( $75.2 \%$ in area) and farmland ( $21.5 \%$ in area; mainly grassland, wheat field and corn field). The soil layer, common to the slope of forest and grassland, consisted of porous organic layer (A layer) less than $0.3 \mathrm{~m}$ thick and organic/inorganic (B layer) about $10 \mathrm{~m}$ or more thick. The B layer is silty clay with low hydraulic conductivity of $10^{-4} \mathrm{~cm} / \mathrm{s}$ order. The 4-channel profilers $(8 \mathrm{~cm}, 18 \mathrm{~cm}, 28 \mathrm{~cm}$ and $38 \mathrm{~cm}$ in soil depth) for measurements of volumetric water content $\left(\mathrm{cm}^{3} / \mathrm{cm}^{3}\right)$ indicated that, common to rainfall and snowmelt events, the 8-28 cm layer at forest stores infiltrated water for a few days after events, and then returns to the previous moisture level by gradual drainage. At grassland, the drainage after events was slight except for $8 \mathrm{~cm}$ depth. At a rainfall of more than 20 $\mathrm{mm} / \mathrm{h}$, the saturated zone appeared at $38 \mathrm{~cm}$ depth in forest and at depths of more than $8 \mathrm{~cm}$ in grassland. Hence, in the events, the percolation and subsurface flow are judged to be active. The percolation at $38 \mathrm{~cm}$ depth of forest and grassland was calculated for rainfall and snowmelt events. Meanwhile, runoff analyses by the tank model revealed that surface and intermediate runoffs occupy more $70 \%$ of rainfall or snowmelt runoffs in the Saromabetsu River. As a result, there existed the linear relationship between the total percolation and surface and intermediate runoffs for the runoff events. Hence, it is suggested that the surface and intermediate runoffs from runoff analyses occur as the percolation and subsequent subsurface flow below the soil surface layer.
\end{abstract}

Key words: soil moisture, rainfall runoff, snowmelt runoff, percolation, tank model, surface runoff, intermediate runoff

\section{Introduction}

Soil moisture is widely recognized as a key parameter in environmental processes, including meteorology, hydrology, agriculture and climate change. From a hydrologic viewpoint, soil moisture controls the partition of rainwater into percolation, storage and drainage, and therefore has an important effect on the runoff behavior of catchments (Aubert et al., 2003). Runoff generation is a highly nonlinear process and threshold processes are observed in many cases (Grayson et al., 1997; Meyles et al., 2003), e.g., saturation excess flow starts when soil storage capacity is filled. The soil type is mainly de-

* 1 Department of Natural History Sciences, Graduate School of Science, Hokkaido University

* 2 Department of Natural History Sciences, Faculty of Science, Hokkaido University 
pendent on parent material (bedrock), local climate and topography, but its management can affect the properties very profoundly. In the previous studies, many researchers pointed out that the macropore flow and the matrix flow in the vadose zone play the important role on runoff generation and streamflow recession, respectively (Dingman, 2002). However, it is very difficult to predict how such flows are formed in the subsurface layer and affect the runoff generation and depletion, since a number of factors affect soil hydrology, including texture, structure, hydraulic conductivity, pore size distribution, and retention characteristics (Nielsen and Hansen, 1973). There are many studies on relations between observed soil moisture distributions and runoff generation on the basin slope (Calvo-Cases et al., 2003; Penna, 2008) or at the small basin scale of 0.01 to $10 \mathrm{~km}^{2}$ order (Harmes and Chanasyk, 1998; Gautam et al., 2000; van Asch et al., 2001; Meyles et al., 2003; Martinez et al., 2008; Penna et al., 2011), but very few investigations on how different the soil moisture variability is between the summer and snowmelt seasons, and on how the observed soil moisture is related to river runoffs modeled on the basin scale of $10^{2} \mathrm{~km}^{2}$ or more order. In this study, in a river basin of $10^{2} \mathrm{~km}^{2}$ order, it is explored how soil water behaviours on the basin slope of different land use affect river runoffs by monitoring the soil moisture content in the summer and snowmelt seasons and by analyzing the river runoffs with a tank model (Sugawara, 1972).

\section{Study area and filed observations}

\section{Study Area}

The Saromabetsu river basin in Hokkaido, Japan $\left(43^{\circ} 49^{\prime}\right.$ to $44^{\circ} 04^{\prime} \mathrm{N}$ and $143^{\circ} 04^{\prime}$ to $144^{\circ} 00^{\prime}$ E), has the area of $387.0 \mathrm{~km}^{2}$ with the maximum elevation of $829 \mathrm{~m}$ a.s.l. (above sea level) at Mt. Nikoro (mean, $203.3 \mathrm{~m}$ a.s.l.) and the mean basin slope angle of $9.73^{\circ}$ (Fig. 1 and Fig. 2a). Fig. 2a was made up on the base of the $10 \mathrm{~m}$ GIS data of Gespatial Information Authority of Japan, Ministry of Land, Infrastructure, Transport and Tourism. The Saromabetsu River is the largest river flowing into a brackish lake, Lake Saroma connected to the Okhotsk Sea. The meteorological records by the Automated Meteorological Data Acquisition System (AMeDAS) at the Saroma town (site $\mathrm{S}$ in Fig. 1; $59.0 \mathrm{~m}$ a.s.l) in $1980-2007$ show the mean annual precipitation of $789 \mathrm{~mm}$ (583mm rainfall of May - November and 206mm snowfall of December - April) and the annual mean air temperature of $5.3^{\circ} \mathrm{C}\left(12.4^{\circ} \mathrm{C}\right.$ in May - November and $-4.6^{\circ} \mathrm{C}$ in December - April). The rainfall records are conducted also at site $\mathrm{E}$ and site $\mathrm{H}$ by the Abashiri District Public Works Management Office. The basin geology is Cretaceous to Paleogenic marine sedimentary rocks in the upstream and downstream areas, and Jurassic to Cretaceous basaltic rocks in the middle area (National Institute of Advanced Industrial Science and Technology, Japan; URL http://www. aist.go.jp/GSJ/bHOK/gguide/Contents/GeoMap/ all/HokGAh.html). The gauging station of the Saromabetsu River is located at the Eidai Bridge in

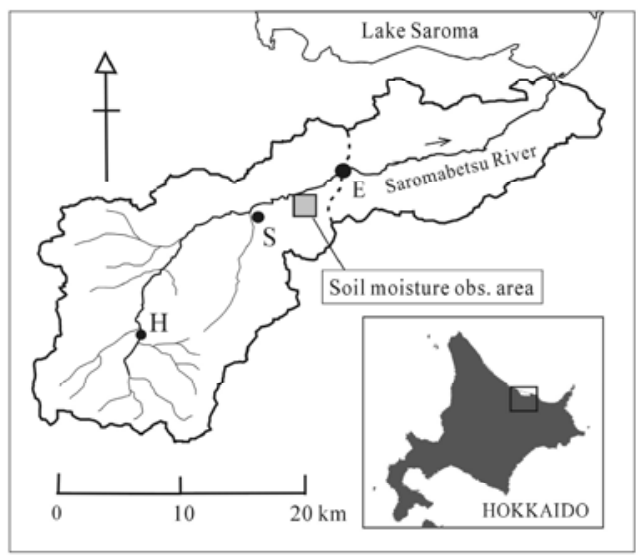

Fig. 1. Location of the Saromabetsu river basin, Hokkaido, and observation sites (site E, river stage and rainfall; site $\mathrm{S}, \mathrm{AMeDAS}$; site $\mathrm{H}$, rainfall). 
the middle reach (site E in Fig. 1), and indicates the discharge of $3.6 \mathrm{~m}^{3} / \mathrm{s}$ averaged in June - November. The basin area upstream of the gauging station is $259.3 \mathrm{~km}^{2}$. The land cover of the upper river basin
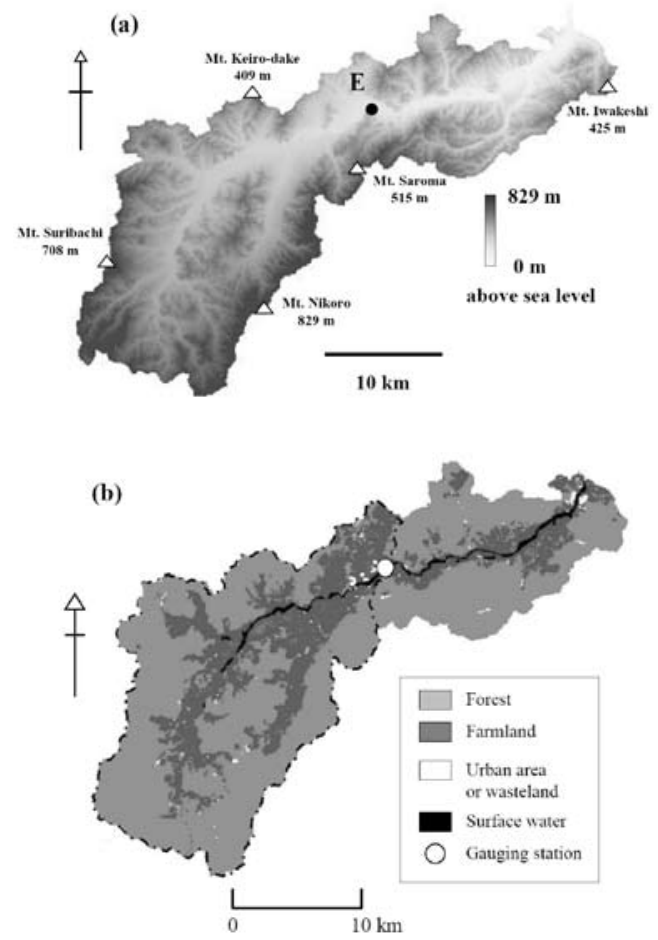

Fig. 2. (a) Digital elevation model with main five mountains and (b) land cover of the Saromabetsu river basin. in 2006 is composed of $75.2 \%$ forest, $21.5 \%$ farmland (60\% grassland and $40 \%$ field), 1.3\% urban area, $1.1 \%$ water surface and $0.9 \%$ wasteland (Fig. 2b: National and Regional Planning Bureau, Ministry of Land, Infrastructure, Transport and Tourism, Japan; URL http://nlftp.mlit.go.jp/ksj/jpgis/datalist/KsjTmpltL03-b.html). The forest is mixed by the needleleaf and broadleaf trees (e.g., Larix kaempferi, Abies sachalinensis, Betula platyphylla var. japonica). The urban area is sporadically located along the river channel, but mostly at the Saroma town just upstream of site E. In this study, the soil water behaviors in the upper Saromabestu river basin is specified by relating runoff analyses at site $\mathrm{E}$ to the soil moisture measurements on the slope upstream of site E (Fig. 1).

The soil moisture was measured at site $\mathrm{A}$ in forest and site $\mathrm{B}$ in grassland in the slope area upstream of site E (Fig. 1 and Fig. 3). The land cover in the slope area consists of forest, grassland, corn field and bareland (white) with a deserted house (black). Ditches 60 to $80 \mathrm{~cm}$ deep below the ground surface are excavated in or around the grassland and field to easily drain snowmelt water or rainwater (Fig. 3b). The slope faces the river channel in the downslope direction (Fig. 3a). Thus, part of

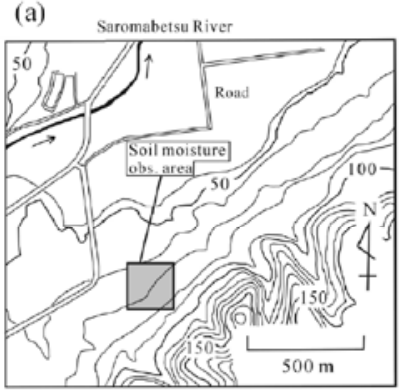

Elevation ( $\mathrm{m}$ asl): $10 \mathrm{~m}$ interval

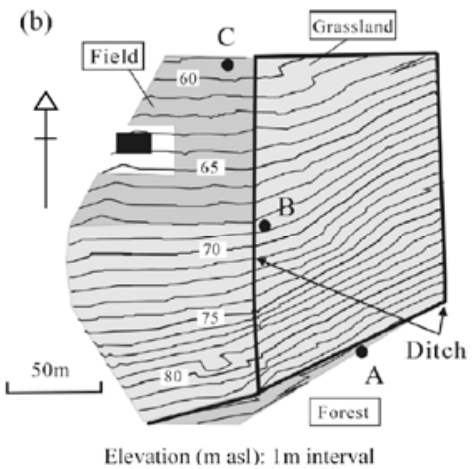

Fig. 3. Location of (a) slope area and (b) sites (site A at forest and site B at grassland) for soil moisture measurements. The infiltration capacity at the ground surface and the hydraulic conductivity of the soil were also obtained at site A, site B and site C (field) (Table 1). 
meltwater or rainwater infiltrated into soils in the slope area could directly flow into the Saromabetsu River. Site A and site B are located at the basal parts of the forest slope and the grassland slope, respectively. The ditch at near site A could then work as a barrier obstructing the input of shallow subsurface water in forest into the grassland. The slope angle is $5.0^{\circ}$ at site $\mathrm{A}$ ( $84.5 \mathrm{~m}$ a.s.l.) in forest, $7.1^{\circ}$ at site $\mathrm{B}$ (68.7 $\mathrm{m}$ a.s.1.) in grassland and $3.5^{\circ}$ at site $\mathrm{C}(59.3 \mathrm{~m}$ a.s.1.) in field (Fig. 3b). The well drilling on the flood plain at $500 \mathrm{~m}$ north of the slope area furnishes the sedimentary information on silty deposits about $35 \mathrm{~m}$ thick above the bedrock with the bottom mineral layer $5 \mathrm{~m}$ thick (personal communication with a dairyman, Mr. K. Yano). The flood plain is developed up to around site S, $7.6 \mathrm{~km}$ upstream of site $\mathrm{E}$, and upstream of around site $\mathrm{S}$, the farmland slope or relatively steep forest slope exists as part of the riparian zone (Fig. 1 and Fig. 2).

\section{Field Observations}

The soil moisture in the slope area was monitored by 2 soil moisture profilers (4-channel probe; Delta-T Devices Ltd., UK, type PR2; accuracy, $\pm 0.002 \mathrm{~cm}^{3} / \mathrm{cm}^{3}$ ) in June 2008 - May 2009. One soil moisture profiler was set at site A on the slope base of forest, and the other at site B in grassland. In June 2008, access tubes of the profilers were inserted carefully into holes in soil layers of sites $\mathrm{A}$ and $\mathrm{B}$, and then the profile probes were set into the access tubes. The soil moisture by the profilers was monitored at the same holes in June 2008 - May 2009 by keeping dry the interior of the access tubes. The measurement intervals are 20 minutes. The profilers measure soil moisture under condition that the square root of the permittivity, $\varepsilon$, for an electromagnetic field is proportional to the volumetric soil moisture content, $\theta\left(\mathrm{cm}^{3} / \mathrm{cm}^{3}\right)$, i.e., $\sqrt{\varepsilon} \propto \theta$. The voltage from the probe, which is proportional to $\sqrt{\varepsilon}$, was stored in a data logger, and, using an empirical formula, changed into $\theta$. The profiler can measure the soil moisture within about $100 \mathrm{~mm}$ in the radial direction from the probe at each depth of $8 \mathrm{~cm}, 18 \mathrm{~cm}, 28 \mathrm{~cm}$ and $38 \mathrm{~cm}$ below the ground surface. The saturated hydraulic conductivity and volumetric moisture content of the soils at site $A$, site $B$ and site $C$ were measured in laboratory. The infiltration capacity at the ground surface in the slope area was in situ measured by a double-ring infiltrometer (Type IV-40063, Turf-Tec, Inc., USA) at site A, site B and site C in July 2008. The seven trials at each site gave us the mean and observational scatter. The density of covered snow was obtained at site A and site B and site S in March and April, in order to get the degree-day factors in the degree-day approach for the calculation of snowmelt amount (Rango and Martinec, 1995).

Two pressure gauges for air pressure and water pressure plus air pressure $\mathrm{HOBO}$ water level loggers; a range of 0 - $207 \mathrm{kPa}$ and accuracy of $\pm 0.10 \mathrm{kPa}$ for pressure and a range of $-20-50^{\circ} \mathrm{C}$ and accuracy of $\pm 0.5^{\circ} \mathrm{C}$ for temperature) were set at site $\mathrm{E}$, in order to record the pressures at $30 \mathrm{~min}$ intervals for a period of January 2008 to May 2009. The water pressure was converted into water depth (m) by dividing the gravitational acceleration (= $\left.9.8 \mathrm{~m} / \mathrm{s}^{2}\right)$ and the water density $\left(\mathrm{kg} / \mathrm{m}^{3}\right)$ at water temperature recorded in the data logger underwater. A rating curve was established on the basis of frequent discharge measurements and simultaneous water depth records. As a result, the discharge includes the $10-15 \%$ observation error.

\section{Observational results and discussion}

\section{Soil moisture variability}

Fig. 4 shows hourly variations of volumetric moisture content $\left(\mathrm{cm}^{3} / \mathrm{cm}^{3}\right)$ at (a) site A (forest) and (b) at site B (grassland), and (c) discharge and (d) rainfall at site $\mathrm{E}$ in the summer season 

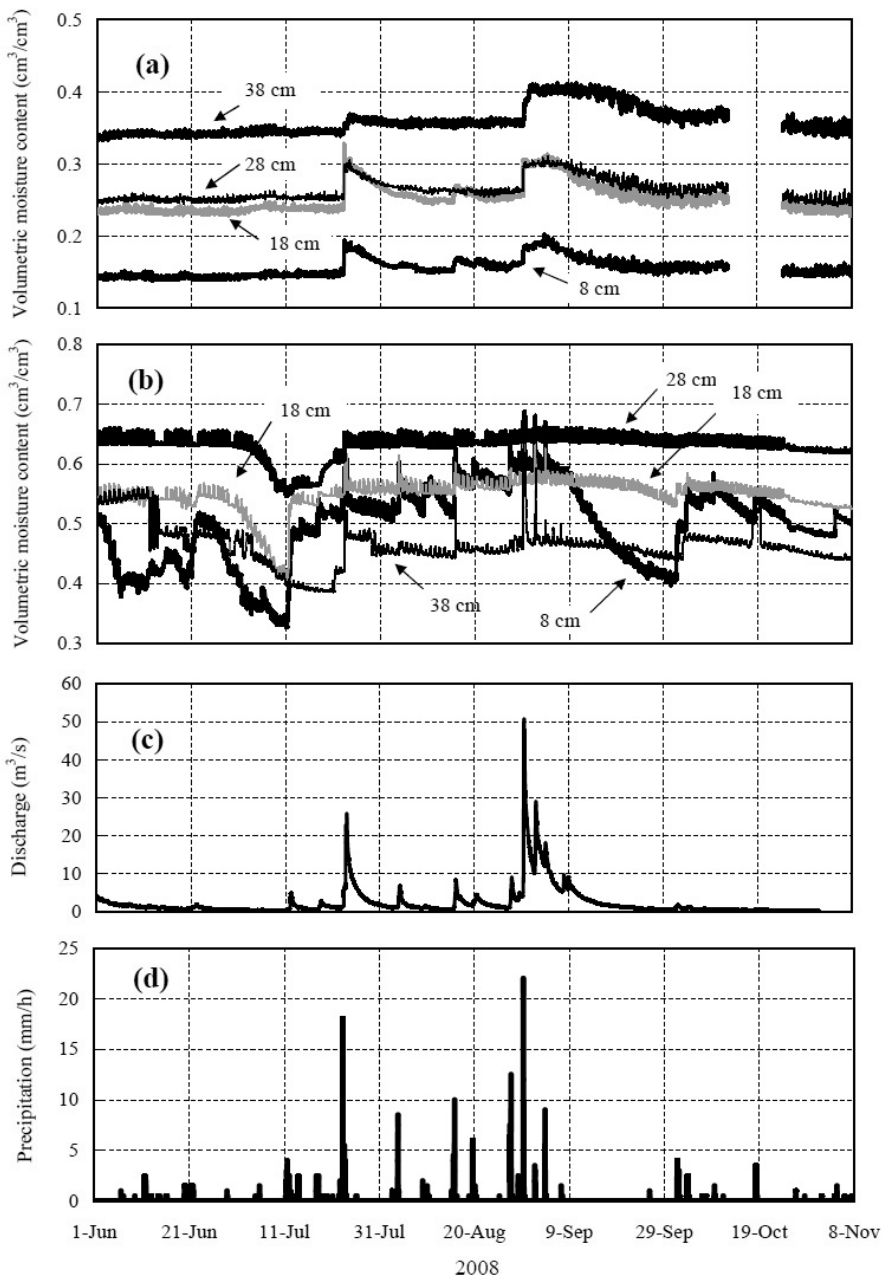

Fig. 4. Temporal variations of volumetric moisture content at (a) forest and (b) grassland, (c) river discharge at site E, and (d) rainfall at site $\mathrm{S}$ in the summer season of 2008.

of 1 June -7 November 2008. At forest (Fig. 4a), the temporal variability of moisture content, being similar at all the soil depths, occurred at rainfall of more than $10 \mathrm{~mm} / \mathrm{h}$, and the drainage after rainfalls is to some degree faster at $8 \mathrm{~cm}$ and $18 \mathrm{~cm}$ than at $28 \mathrm{~cm}$ and $38 \mathrm{~cm}$. The soils at depths of $8 \mathrm{~cm}, 18$ $\mathrm{cm}, 28 \mathrm{~cm}$ and $38 \mathrm{~cm}$ exhibited water saturation at $0.40,0.44,0.43$ and $0.43 \mathrm{~cm}^{3} / \mathrm{cm}^{3}$, respectively. All of the water storages and drainages thus occurred under unsaturated condition. The similar variability at all the depths probably reflects non disturbance in structure, and the gradual downward increase of the moisture content as the whole indicates the downward decrease of pore size or the downward fineness in texture.

At grassland (Fig. 4b), the moisture content varied in different ways at $0 \mathrm{~cm}$ to $38 \mathrm{~cm}$ depth; at $8 \mathrm{~cm}$ depth, water content increased greatly at the rainfall of $4 \mathrm{~mm} / \mathrm{h}$ on 11 July. Thereafter, following the continual rainfalls, increased gradually until 4 September, and then decreased greatly under no rainfalls. At $18 \mathrm{~cm}$, the moisture content similarly 
increased in response to the rainfall of $4 \mathrm{~mm} / \mathrm{h}$ on 11 July, but, thereafter, maintained the similar moisture level of 0.53 to $0.58 \mathrm{~cm}^{3} / \mathrm{cm}^{3}$. At $28 \mathrm{~cm}$ and $38 \mathrm{~cm}$ depths, the moisture content increased in response to the small rainfall of 17 July and the large rainfall of 23 July, respectively, and, thereafter, maintained the similar moisture level of $0.63-0.65$ $\mathrm{cm}^{3} / \mathrm{cm}^{3}$ and $0.45-0.48 \mathrm{~cm}^{3} / \mathrm{cm}^{3}$, respectively. The grassland soils at $8 \mathrm{~cm}, 18 \mathrm{~cm}, 28 \mathrm{~cm}$ and $38 \mathrm{~cm}$ depth showed water saturation at $0.60,0.65,0.68$ and $0.63 \mathrm{~cm}^{3} / \mathrm{cm}^{3}$, respectively. The soils at 18 and 28 $\mathrm{cm}$ depth thus tend to become nearly saturated and almost saturated by the small rainfalls, respectively, while they at 8 and $38 \mathrm{~cm}$ depth get into saturation only by large rainfalls of more than $20 \mathrm{~mm} / \mathrm{h}$. In a period of 22 June to 10 July with few rainfalls, the moisture content consistently decreased especially at depths of $8 \mathrm{~cm}$ and $18 \mathrm{~cm}$. Part of the decrease is probably due to the evaporation of soil water.

On the whole, the sensitivity to rainfalls is higher at grassland than at forest. This probably results from the high effective rainfall or the small interception of rainwater at grassland. The moisture content at grassland is more than $0.3 \mathrm{~cm}^{3} / \mathrm{cm}^{3}$ at all the depths, whereas that at forest is at any time more than $0.3 \mathrm{~cm}^{3} / \mathrm{cm}^{3}$ only at a depth of $38 \mathrm{~cm}$. This means that the A layer, including the root zone, at forest is relatively porous and thick.

At the large rainfalls producing river discharge of more than $20 \mathrm{~m}^{3} / \mathrm{s}$, the forest soil stores infiltrated water similarly at all the depths, and, after the rainfalls, releases the stored water smoothly (Fig. 5a). At grassland, the drainage after the rainfalls occurs significantly only at $8 \mathrm{~cm}$ depth (Fig. 5b). The vertical measurement of soil moisture at wheat field in the slope area by Yagisawa (2008) indicated that the rainwater storage and drainage occur markedly only at $8 \mathrm{~cm}$ depth. In Fig. 4 , it is seen that the soil moisture at $8 \mathrm{~cm}$ depth of grassland is sensitive even to rainfalls of less than $10 \mathrm{~mm} / \mathrm{h}$ producing
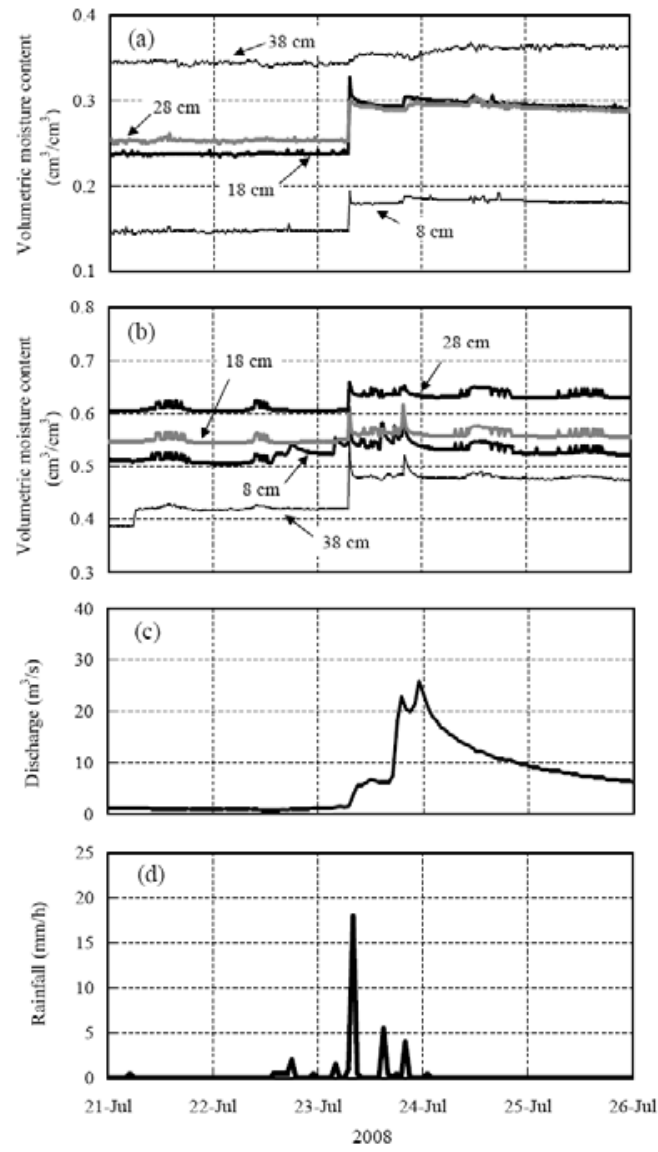

Fig. 5. Temporal variations of volumetric moisture content at (a) forest and (b) grassland, (c) river discharge at site $\mathrm{E}$, and (d) rainfall at site S for 21 - 25 July 2008.

river discharge of less than $10 \mathrm{~m}^{3} / \mathrm{s}$. Meanwhile, the forest soils, showing a definite response to rainfalls of more than $15 \mathrm{~mm} / \mathrm{h}$ generating discharge of more than $20 \mathrm{~m}^{3} / \mathrm{s}$, tend to produce the rainwater storage and drainage at all the depths (especially, at $8 \mathrm{~cm}, 18 \mathrm{~cm}$ and $28 \mathrm{~cm}$ depth) (Fig. 5a). Thus, the large river runoffs likely occur in relation to the water storage and drainage in forest and the $0-10 \mathrm{~cm}$ layer of farmland. On daytime with no rainfalls, the moisture content increased by 0.012 to $0.014 \mathrm{~cm}^{3} / \mathrm{cm}^{3}$ at depths of less than $38 \mathrm{~cm}$ at grassland (Fig. 5b). This results from the rise of soil water, probably due to the water absorption by grass 
roots, following the transpiration. On daytime of 24 July, when the water rise was largest at grassland, the forest soil also increases the moisture content slightly. Little or no water rise at forest (Fig 5a) is probably caused by the little or non transpiration, which is produced during the evaporation from wet leaves between the rainfalls (Fig. 4d).

Table 1 shows infiltration capacity $(\mathrm{mm} / \mathrm{h})$ at the ground surfaces of site A (forest), site B (grassland) and site $\mathrm{C}$ (field), and saturated hydraulic conductivity $(\mathrm{cm} / \mathrm{s})$ at $35 \mathrm{~cm}$ and $75 \mathrm{~cm}$ depth of the three sites. The similar hydraulic conductivity at forest and grassland reflects the similar pore size or texture at depths of $35 \mathrm{~cm}$ or more. The infiltration capacity much larger than the rainfalls in Fig. $4 \mathrm{~d}$ means that any Hortonian overland flows do not occur at the three sites. Meanwhile, the hydraulic conductivity at depths of $35 \mathrm{~cm}$ and $75 \mathrm{~cm}$ is relatively low at the order of $10^{-4} \mathrm{~cm} / \mathrm{s}$. This suggests that, because of the small percolation, the saturated zone is produced at depths of $38 \mathrm{~cm}$ or more.

Fig. 6 shows hourly variations of volumetric moisture content $\left(\mathrm{cm}^{3} / \mathrm{cm}^{3}\right)$ at (a) site A (forest) and (b) at site B (grassland), and (c) discharge, (d) precipitation, snow depth and air temperature at site E in the snowmelt season of 4 March - 22 May 2009. The soil moisture measurement at forest ceased on 15 April, due to the battery trouble. The snowmelt river runoffs in March appeared sporadically by snowmelt (and rainfall) under positive air temperature, but the relatively large runoffs after 3 April occurred by continuous positive air temperature (Fig. $6 \mathrm{c}$ and Fig. 6d). The largest snowmelt river runoffs occurred on 10 April after the snow at site S disappeared. As a characteristic of the moisture records in the snowmelt season, the moisture content varied daily at all the depths of forest and at $8 \mathrm{~cm}$ depth of grassland. This indicates that the percolation in the surface layer of forest and just below the ground surface of grassland is sensitive to the snowmelt amount at the snow surface. After 3 April, showing positive air temperature on almost all the days, the moisture content varied daily also at all the depths of grassland. Especially, the moisture content at $38 \mathrm{~cm}$ depth varies greatly until 11 April, corresponding to the great daily variation of river discharge. The soil moisture variability at $38 \mathrm{~cm}$ depth of grassland also corresponds to the river runoffs before 3 April. This suggests that, at the abrupt large snowmelt, in addition to the percolation in the soil layer of forest, the percolation at depths of more than $38 \mathrm{~cm}$ of grassland plays the important role on the runoffs.

On the whole, the temporal patterns of soil moisture are similar to those in the summer season (Fig. 4a and Fig. 4b); the meltwater (sometimes, plus rainwater) storage and drainage occur markedly at 8 to $28 \mathrm{~cm}$ depths of forest and at $8 \mathrm{~cm}$ depth of grassland. Especially, the moisture variability at $18 \mathrm{~cm}$ and $28 \mathrm{~cm}$ depth of forest corresponds to the temporal variability of discharge including the peak discharges of 10 and 14 April. This suggests that the main snowmelt runoffs are produced in close relation to the meltwater storage and drainage between $18 \mathrm{~cm}$ and $28 \mathrm{~cm}$ depths at forest.

The large peak discharge of 1 May was produced by the melt of snow newly accumulated on

Table 1 . Infiltration capacity and saturated hydraulic conductivity, $K_{s}$, at $35 \mathrm{~cm}$ and 75 $\mathrm{cm}$ depth of forest (site A), grassland (site B) and field (site C).

\begin{tabular}{cccc}
\hline & $\begin{array}{c}\text { Infiltration capacity } \\
(\mathrm{mm} / \mathrm{hr})\end{array}$ & $\begin{array}{c}K_{s} \text { at } 35 \mathrm{~cm} \\
(\mathrm{~cm} / \mathrm{s})\end{array}$ & $\begin{array}{c}K_{s} \text { at } 75 \mathrm{~cm} \\
(\mathrm{~cm} / \mathrm{s})\end{array}$ \\
\hline Forest & $3,240 \pm 280$ & $1.7 \times 10^{-4}$ & $1.3 \times 10^{-4}$ \\
Grassland & $270 \pm 65$ & $5.3 \times 10^{-4}$ & $3.9 \times 10^{-4}$ \\
Field & $576 \pm 92$ & $4.3 \times 10^{-4}$ & $3.9 \times 10^{-4}$ \\
\hline
\end{tabular}



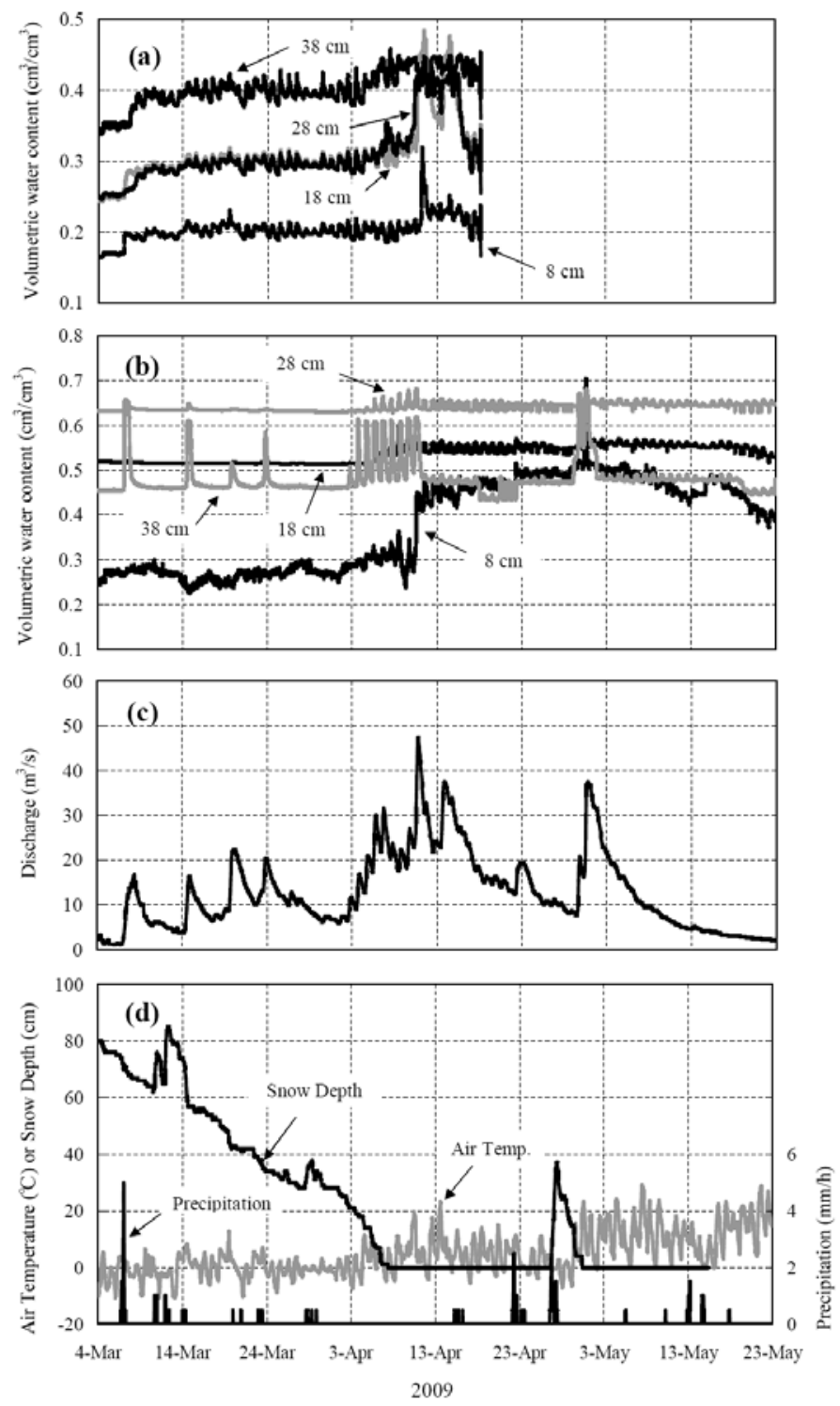

Fig. 6. Temporal variations of volumetric moisture content at (a) forest and (b) grassland, (c) river discharge at site E, and (d) snow depth, air temperature and precipitation at site $S$ in the snowmelt season of 2009 .

26 - 27 April (Fig. 6c and Fig. 6d). Corresponding to the runoff, the moisture content at grassland varied greatly at depths of $8 \mathrm{~cm}, 18 \mathrm{~cm}$ and $38 \mathrm{~cm}$, and, at the maximum moisture content of $1320 \mathrm{~h}$ - 1520h, 30 April, the soil at depths of $8-38 \mathrm{~cm}$ was simultaneously saturated. Then, the saturation overland flow, contributing to part of the runoff, possibly occurred. At $0500 \mathrm{~h}-1600 \mathrm{~h}$ of 10 April, the air temperature increased up to $20{ }^{\circ} \mathrm{C}$ at maximum. Then, the moisture content at $8 \mathrm{~cm}$ depth of grassland abruptly increased from 0.29 to $0.44 \mathrm{~cm}^{3} / \mathrm{cm}^{3}$, and thereafter, maintained the similar moisture level $\left(0.44-0.52 \mathrm{~cm}^{3} / \mathrm{cm}^{3}\right)$ until the morning of 30 April. The low drainage, compared with that at $8 \mathrm{~cm}$ 
depth of forest, could thus provide the occurrence of such an overland flow.

As shown by Fig. $4 \mathrm{~b}$ and Fig. $6 \mathrm{~b}$, at $38 \mathrm{~cm}$ depth of grassland, there appeared the very high response (rapid water storage up to the near saturation and rapid drainage to the previous moisture level) to rainfall and snowmelt events. This may occur, also when there is some space between the access tube of the profiler's probe and the surrounding soil layer. However, the effect of such space during the moisture measurements is considered to be low, if the linear relationship is established between the percolation amount and simulated runoffs calculated for the events.

\section{Calculation of the percolation amount Preparation}

The soil moisture observations indicated that the percolation in the soil surface layer of forest and at $38 \mathrm{~cm}$ depth of grassland may be related to the rainfall and snowmelt river runoffs. The amount of percolation is here calculated to know what volume of soil water moves in each of rainfall and snowmelt events. The soil layer at 0 to $38 \mathrm{~cm}$ depths is divided into four layers $(i=1,2,3,4)$ of $0-8 \mathrm{~cm}, 8-18 \mathrm{~cm}$, $18-28 \mathrm{~cm}$ and $28-38 \mathrm{~cm}$ depth, respectively. First, the total moisture content, $W_{i, t}(\mathrm{~mm})$, of the $i$ layer at a time $t$ was calculated as follows:

$$
W_{i, t}=\left\{\begin{array}{l}
\theta_{i, t} \times 80 \quad(i=1) \\
\frac{\left(\theta_{i, t}+\theta_{i-1, t}\right)}{2} \times 100 \quad(i=2,3,4)
\end{array}\right\}
$$

where $\theta_{i, t}$ is the volumetric moisture content $\left(\mathrm{cm}^{3} / \mathrm{cm}^{3}\right)$ at depths of $8 \mathrm{~cm}, 18 \mathrm{~cm}, 28 \mathrm{~cm}$ and $38 \mathrm{~cm}$ ( $i=1,2,3$ and 4, respectively). As shown by the first equation of Equation (1), the volumetric moisture content within the $(i=1)$ layer was assumed to be constant at $\theta_{1, t}$. Using the water content, $W_{i, t}$, and assuming the moisture content to be horizontally uniform, the equation of continuity is given as

$$
\frac{\partial W}{\partial t}=-\left(\frac{\partial q_{z}}{\partial z}\right)
$$

where $q_{z}$ is the downward flow rate $(\mathrm{mm} / \mathrm{s})$. Here $\mathrm{Z}$ is positive downward from the ground surface. Applying Equation (2), the percolation amount, $q_{i, t_{1}-t_{2}}(\mathrm{~mm})$, at a depth of $i$ at between $t_{1}$ and $t_{2}$ is approximately obtained by the following equations (Nakano et al., 1995):

$$
q_{i, t_{1}-t_{2}}=q_{0, t_{1}-t_{2}}-\sum_{m=1}^{i}\left(W_{m, t_{2}}-W_{m, t_{1}}\right)
$$

Here, the effective rainfall or snowmelt amount, $P_{t_{1}-t_{2}}$ $(\mathrm{mm})$, at the ground surface at between $t_{1}$ and $t_{2}$ was given to $q_{0, t_{1}-t_{2}}$ as shown by equation (4):

$$
q_{0, t_{1}-t_{2}}=P_{t_{1}-t_{2}}
$$

The infiltration, $q_{0, t-1-t}$, at the ground surface of site $\mathrm{A}$ and site $\mathrm{B}$ was assumed to be equal to rainfall and/or snowmelt amount, although it is probably overestimated by the interception of rainwater and snow, especially in forest. The snowmelt amount at site $\mathrm{A}$ and site $\mathrm{B}$ was obtained by applying the data of air temperature and snow depth at site $\mathrm{S}$ to the degree-day method and by obtaining air temperature at the altitudes of the two sites from the lapse rate. Using the air temperature data at the meteorological stations in or around the Saromabetsu river basin, the lapse rate was obtained at $0.3^{\circ} \mathrm{C} / 100 \mathrm{~m}$. Then, the degree-day factor was obtained by measuring the snow density in situ at forest and grassland and site $\mathrm{S}$, and by comparing the snow depth records at site $\mathrm{S}$ with the positive degree days. As a result, the snow density was $380 \mathrm{~kg} / \mathrm{m}^{3}$ on average, and the degree-day factors were determined at 4.2 $\mathrm{mm} /{ }^{\circ} \mathrm{C} \cdot$ day at forest and at $5.1 \mathrm{~mm} /{ }^{\circ} \mathrm{C} \cdot$ day at grassland and site $\mathrm{S}$. The snow-covered conditions at sites $\mathrm{A}$ and $\mathrm{B}$ were judged by knowing a temporal change of snow-covered area in the river basin. The snow cover change was acquired by the digital 
elevation map (Fig. 2a), the lapse rate and the degree-day factor. The spatial snow cover distribution obtained was ascertained by the MODIS/Terra Snow Cover 8-day L3 Global 500m Grid, version 5 (URL: http://nsidc.org/data/mod10a2v5.html) (Hall et al., 2006).

\section{Calculated results}

Fig. 7 shows time series of the hourly percolation, $q_{4, t_{1}-t_{2}}(\mathrm{~mm} / \mathrm{h}$ ), at $38 \mathrm{~cm}$ depth of (a) site A (forest) and (b) site B (grassland), and (c) the rainfalls at site $\mathrm{S}$ in a period of the rainfall events of 2008 . As a result, the percolation at grassland is smaller than that at forest except for the first large rainfall of 23 July, but occurs a longer time by the earlier response to the rainfalls.

Fig. 8 shows time series of the hourly percolation at $38 \mathrm{~cm}$ depth of (a) site A and (b) site B, and (c) air temperature and rainfall at site $\mathrm{S}$, and the rainfall plus the calculated snowmelt amount at sites A and B in a period of the snowmelt events of 2009. After 24 March, the percolation at forest was consistently larger than at grassland. This is probably because the meltwater infiltration occurred also on the forest slopes of the altitude higher than at site A. After 1500h, 4 April, the meltwater infiltration at sites $\mathrm{A}$ and $\mathrm{B}$ was depleted because the snow almost vanished there. Discharge of more than $10 \mathrm{~m}^{3} / \mathrm{s}$, beginning at $1500 \mathrm{~h}, 3$ April, continued until 1100h, 26 April, including the two peak river
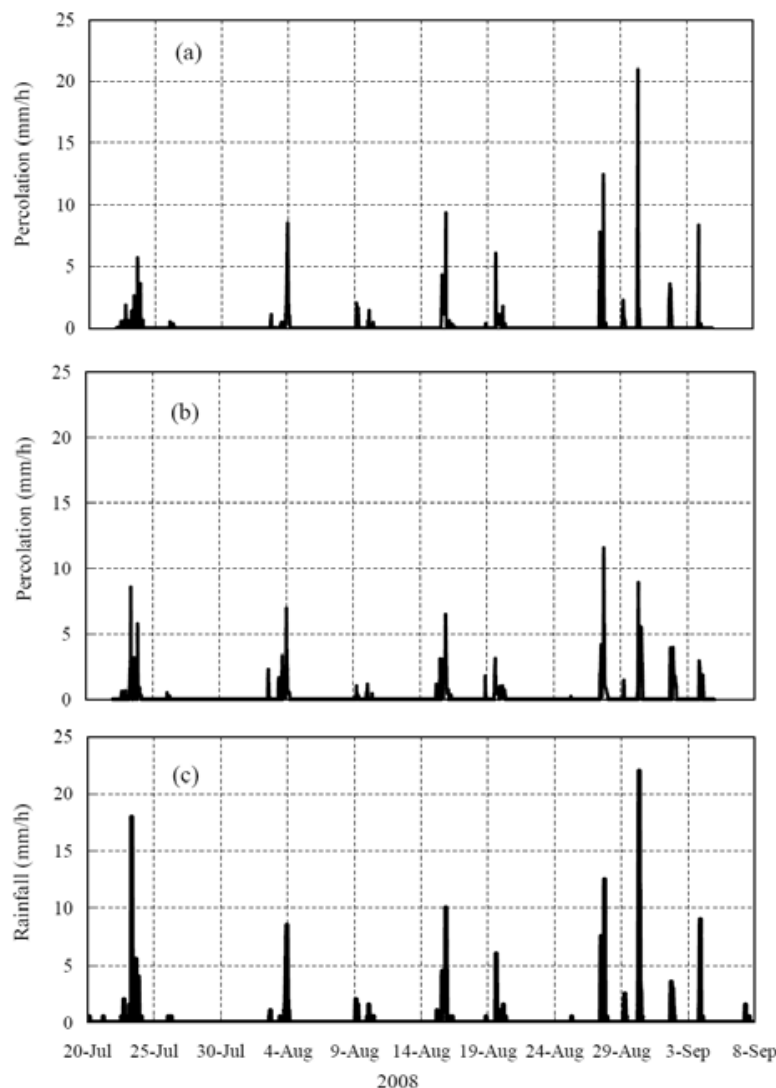

Fig. 7. Time series of the hourly percolation at $38 \mathrm{~cm}$ depth of (a) site $\mathrm{A}$ and (b) site $\mathrm{B}$, and (c) rainfalls at site $\mathrm{S}$ in the summer season of 2008. 

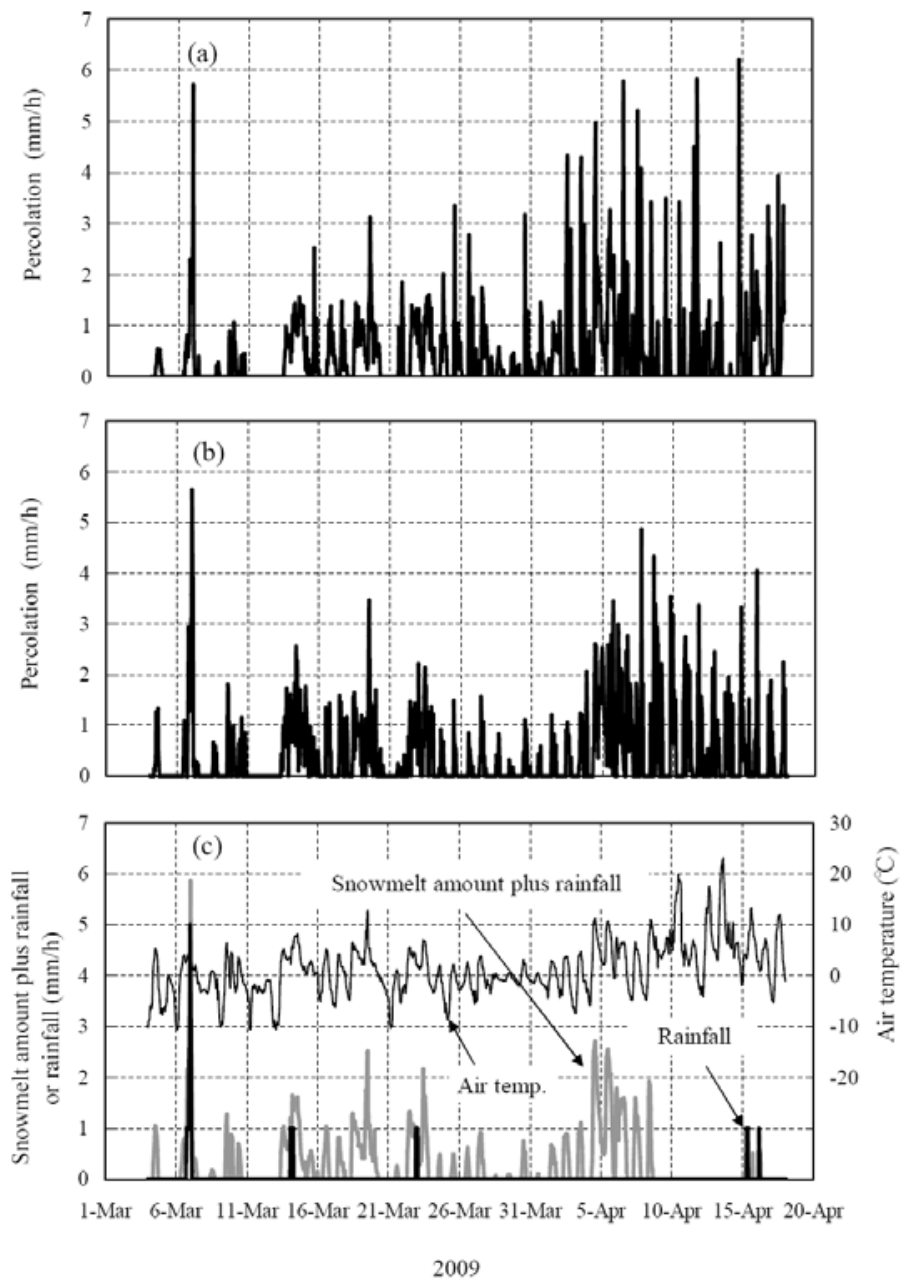

Fig. 8. Time series of the hourly percolation at $38 \mathrm{~cm}$ depth of at (a) site $\mathrm{A}$ and (b) site $\mathrm{B}$, and (c) air temperature and rainfall at site $\mathrm{S}$ and snowmelt amount plus rainfall at site A and site B in the snowmelt season of 2009.

discharges at 1900h, 10 April and at 2100h, 13 April to $0000 \mathrm{~h}, 14$ April (Fig. 6). Such large river runoffs appear to have been produced by the relatively large percolation at forest.

\section{Simulations of rainfall and snowmelt river runoffs}

\section{Preparation}

The rainfall and snowmelt runoffs of the Saromabetsu River are simulated by the tank model
(Sugawara, 1972). The adoption of a lumped model such as the tank model is due to unsatisfactory results by many distributed models for snowmelt river runoffs (Hollander et al., 2009). The tank model (or the linear reservoir model or the HVB-ETH model) is also applicable to simulations of glacier-melt runoffs (Braun and Renner, 1992; Hannah and Gurnell, 2001; Kido et al., 2007) and to those of river runoffs including the rainfall and glacier-melt runoffs (Wada et al., 2007). The three sequential tanks were used to separate the runoffs into three flow components, 
surface runoff, intermediate runoff and baseflow (Fig. 9).

The actual evapotranspiration from the river basin upstream of site $\mathrm{E}$ as output from the top tank was calculated as follows: First, the potential evapotranspiration, $P E$ (cm/day), upstream of site $\mathrm{E}$ was determined by the following Penman equation (Kayane, 1980).

$$
P E=\frac{\left[8.64 \times 10^{6} \cdot\left(Q^{*}-Q_{G}\right) / \rho \lambda\right] \Delta+\gamma E_{a}}{\Delta+\gamma}
$$

where $\lambda$ is the latent heat of vaporization in $\mathrm{J} / \mathrm{kg}$, $\rho$ is the water density in $\mathrm{kg} / \mathrm{m}^{3}, \Delta \equiv d e_{s} / d T\left(e_{\mathrm{s}}\right.$ and $T$, the saturation vapor pressure in $\mathrm{hPa}$ and air temperature in ${ }^{\circ} \mathrm{C}$ at the evaporating surface, respectively), $\gamma \equiv c_{p} \cdot P /(0.622 \lambda),\left(c_{p}\right.$, the specific heat for constant pressure in $\mathrm{J} / \mathrm{kg} \cdot \mathrm{K} ; P$, the air pressure in $\mathrm{hPa}), Q_{G}$ is the conductive heat in $\mathrm{W} / \mathrm{m}^{2}$ to the ground, $Q *$ is the net radiation in $\mathrm{W} / \mathrm{m}^{2}$ given by $Q^{*}$ $=(1-\alpha) K \downarrow+L^{*}$ ( $\alpha$, the albedo; $K \downarrow$, the downward shortwave radiation; $L^{*}$, the net longwave radiation), and $E_{a}$ is the drying power of air, given by $E_{a}=\left(0.013+0.0016 u_{2}\right)\left(e_{s a}-e_{a}\right)$ in $\mathrm{cm} /$ day $\left(u_{2}\right.$, the wind speed in $\mathrm{km} /$ day at $2 \mathrm{~m}$ above the ground surface; $e_{s a}$ and $e_{a}$, the saturation vapor pressure and the vapor pressure in $\mathrm{hPa}$ at the air temperature, $T_{a}$, respectively) (Dunne and Leopold, 1978). The

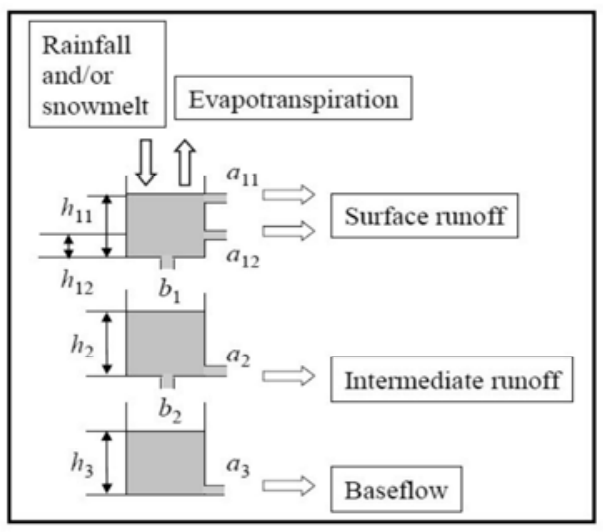

Fig. 9. Schematic diagram of the tank model applied in this study. coefficient of $8.64 \times 10^{6}$ in Equation (5) is used to change $\mathrm{m} / \mathrm{s}$ to $\mathrm{cm} /$ day for numerical values of the bracket. Referring to Kayane (1980), the downward shortwave radiation in ly/min, $K \downarrow=(0.18+0.55 \cdot n)$ $N) K \downarrow_{p}(n$, the daylight time in hr, $N$, the potential daylight time in hr; $K \downarrow_{p}$, the potential shortwave radiation) and the net longwave radiation in ly/min, $L^{*}=-\sigma\left(T_{a}+273.2\right)^{4} \cdot\left(0.366-0.036 \sqrt{e_{a}}\right)(0.1+0.9$. $n / N)\left(\sigma\right.$, the Stefan-Boltzman constant, $1.183 \times 10^{-7}$ $\mathrm{cal} / \mathrm{cm}^{2} \cdot$ day $\cdot \mathrm{K}$ ) were applied, and the albedo, $\alpha=0.2$, was adopted.

The spatial distributions of air temperature corrected in elevation were then applied to the air temperature, $T_{a}$. The air pressure, $P$, was also corrected in elevation by using the air pressure record at site $\mathrm{E}$ and the Abashiri Meteorological Observatory (37.6 $\mathrm{m}$ a.s.1.) about $42 \mathrm{~km}$ east of site E. The other meteorological factors for the calculation of the potential evaporation were observed at site $\mathrm{S}$ and the Abashiri Meteorological Observatory. The actual evapotranspiration, $A E$, was numerically obtained by the short-term water budget method for periods before and after rainfall events. As a result, the evapotranspiration ratio, $\beta(=A E / P E)$, was estimated at 0.80 . The total snowmelt amount in the river basin as input to the top tank in the snowmelt season was calculated by applying the spatial distributions of snow cover and air temperature to the degree-day method. Then, referring to Rango and Martinec (1995), the degree-day factors, $f=4.2$ and $5.1 \mathrm{in} \mathrm{mm} /{ }^{\circ} \mathrm{C} \cdot$ day, were applied to calculate the snowmelt amount at site $\mathrm{A}$ and site $\mathrm{B}$, respectively. The comparison with the MODIS/Terra Snow Cover indicated that the temporal change of the snow-covered area in the river basin was reasonably built up.

Parameters of the tank model are side outlet coefficients $a_{i, j}$ (for the $j$ th side outlet of the $i$ th tank), bottom outlet coefficients, $b_{i}(i=1,2)$, heights, $h_{i j}$, of side outlets and initial storages, $h_{i}(i=1,2,3)$, 
in tanks (Fig. 9). The discharge, $q$ (mm/day), and percolation, $p(\mathrm{~mm} /$ day), from the tanks can then be described by the following equations.

$$
\begin{gathered}
q_{i, j}(n)=\left\{\begin{array}{ll}
a_{i, j} \cdot\left(h_{i}(n)-h_{i, j}\right) & \text { when } h_{i}(n)>h_{i, j}(i=1, j=1,2) \\
0 & \text { when } h_{i}(n) \leq h_{i, j}(i=1, j=1,2)
\end{array}\right\} \\
q_{i}(n)=a_{i} \cdot h_{i}(n) \quad(i=2,3) \\
p_{i}(n)=b_{i} \cdot h_{i}(n) \quad(i=1,2) \\
h_{i}(n)=\left\{\begin{array}{l}
h_{i}(n)-q_{i}(n) \cdot \Delta t-p_{i}(n) \cdot \Delta t+P(n) \cdot \Delta t-E(n) \cdot \Delta t \quad(i=1) \\
h_{i}(n)-q_{i}(n) \cdot \Delta t-p_{i}(n) \cdot \Delta t+p_{i-1}(n) \cdot \Delta t \quad(i=2,3)
\end{array}\right\}
\end{gathered}
$$

where $n$ is the number of day in a simulated period, $\Delta t$ is the time step (=1 day), $a_{i}$ is the discharge rate ( $1 /$ day), $b_{i}$ is the percolation rate (1/day), $h_{i, j}$ and $h_{i}$ are the water levels or storage $(\mathrm{mm}), p_{i}$ is the percolation ( $\mathrm{mm} /$ day), $P(n)$ is the snowmelt amount and/or rainfall ( $\mathrm{mm} /$ day), and $E$ is the actual evapotranspiration ( $\mathrm{mm} /$ day). The total runoff from the drainage basin is given by the sum of discharges from the three tanks as $Q(n)=\sum_{i=1}^{3} q(i, n)$.

\section{Simulated results}

Fig. 10 shows (a) a comparison between simulated discharge and observed one at site E, (b) three flow components separated into surface runoff, intermediate runoff and baseflow, and (c) calculated actual evapotranspiration, and (d) diurnal rainfalls at site $\mathrm{S}$ in the summer season of 2008. The parameters applied to the simulation is shown in Table 2. As a result, the total actual evapotranspiration of 1 June - 7 November 2008 was 277 $\mathrm{mm}$ (Fig. 10c), corresponding to $74 \%$ of the total rainfall. The simulated result is very reasonable to the observed discharge with $r^{2}=0.934, R M S E=0.902$ $\mathrm{m}^{3} / \mathrm{s}, N A S H=0.953 \mathrm{~m}^{3} / \mathrm{s}$, where $r$ is the correlation coefficient, RMSE is the root mean square error and $N A S H$ is the Nash-Sutcliffe model efficiency coefficient (Nash and Sutcliffe, 1970). As a result, for the three large runoffs of 23 July - 2 August, $15-25$ August and 27 August - 14 September, the surface runoff, the intermediate runoff and the baseflow occupied 51.1\%, 46.5\% and 54.4\% (mean, $50.7 \%$ ), $30.9 \%, 22.7 \%$ and $28.2 \%$ (mean, $27.3 \%$ ), and $18.0 \%, 30.8 \%$ and $17.4 \%$ (mean, $22.0 \%$ ), respectively (Fig. 10b). Thus, a quick flow such as the surface flow prevails in the runoff events. Actually, the surface runoff may correspond to the percolation in the surface soil layer, since the infiltration capacity at forest and farmland is much larger than the rainfalls (Table 1).

Fig. 11 shows a comparison between simulated and observed discharges and the three flow components in the snowmelt season of 2009. The simulation was also reasonable to the observed discharge with $r^{2}=0.973, R M S E=0.961 \mathrm{~m}^{3} / \mathrm{s}, N A S H=0.974 \mathrm{~m}^{3} /$ s. Over the period of 6 March to 17 May, the surface runoff, the intermediate runoff and baseflow occupied $34.3 \%, 43.3 \%$ and $22.4 \%$, respectively. Thus, the contribution of the intermediate runoff is relatively large, compared with that in the summer season. This results from relatively large $a_{2}$ and $b_{1}$ values in Table 2, which actually reflects the occurrence of the relatively deep percolation in the snowmelt season, as shown by the increase of soil moisture content at $38 \mathrm{~cm}$ depth (Fig. 6a and Fig. 6b).

\section{Relations between simulated runoffs and percolation}

In order to examine how the calculated percolation affects the river runoff, the simulated surface runoff and intermediate runoff were summed for each event in the summer season of 2008 and the snowmelt season of 2009, and then compared with the total percolation, which was calculated for each event period by using the time series of percolation 

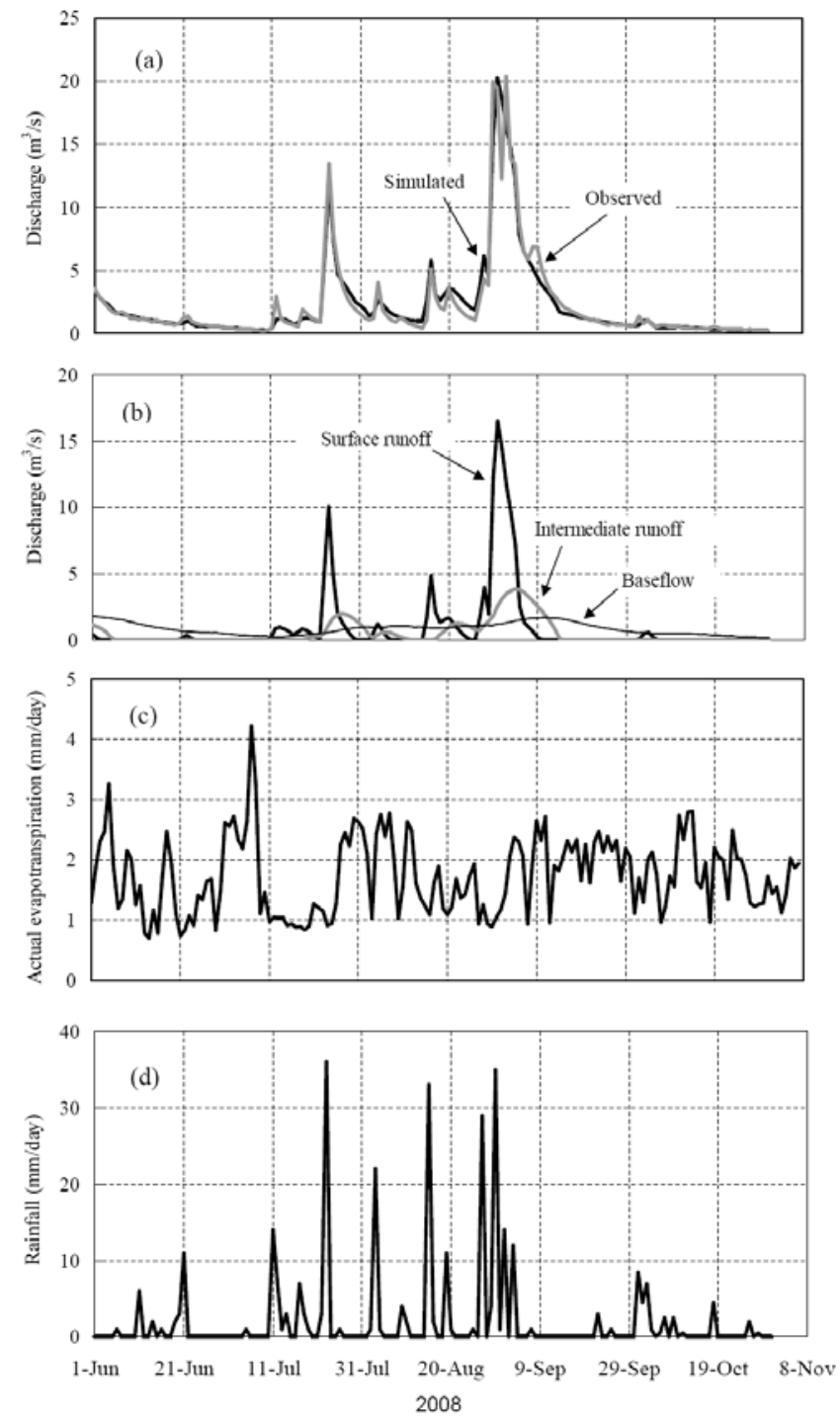

Fig. 10. (a) Comparison between simulated and observed discharges, (b) three flow components separated by the tank model, (c) calculated actual evapotranspiration, and (d) daily rainfalls in the summer season of 2008.

Table 2. Parameters applied to runoff simulations.

\begin{tabular}{ccc}
\hline Parameters & 2008 summer & 2009 spring \\
\hline$h_{11}$ & $23 \mathrm{~mm}$ & $36 \mathrm{~mm}$ \\
$h_{12}$ & $7 \mathrm{~mm}$ & $18 \mathrm{~mm}$ \\
$a_{11}$ & 0.00848 & 0 \\
$a_{12}$ & 0.00161 & 0.00839 \\
$b_{1}$ & 0.00484 & 0.00773 \\
$a_{2}$ & 0.00368 & 0.00475 \\
$b_{2}$ & 0.00383 & 0.00173 \\
$a_{3}$ & 0.00105 & 0.00154 \\
\hline
\end{tabular}

in Fig. 7 and Fig. 8. In the snowmelt season of 2009, the four runoff events of 6 - 10 March, $13-17$ March, 19-28 March and 2-17 April were chosen, while, in the summer season of 2008 , the three river runoffs of $23-29$ July, $15-25$ August and 27 August - 9 September was selected. The summed runoffs were divided by the basin area $\left(259.3 \mathrm{~km}^{2}\right)$ to be expressed as the runoff height (mm). 


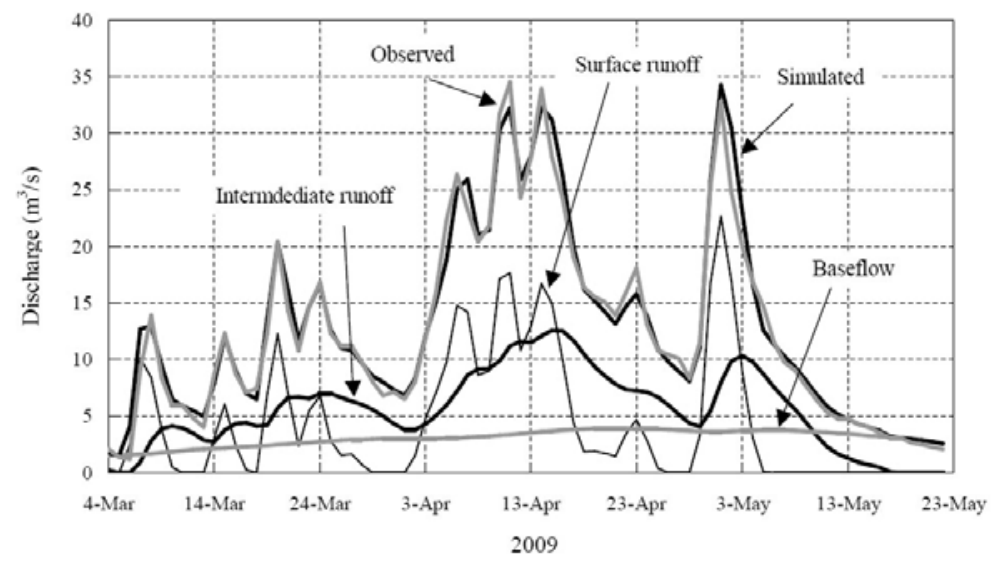

Fig. 11. Comparison between simulated and observed discharges and separated three flow components in the snowmelt season of 2009.
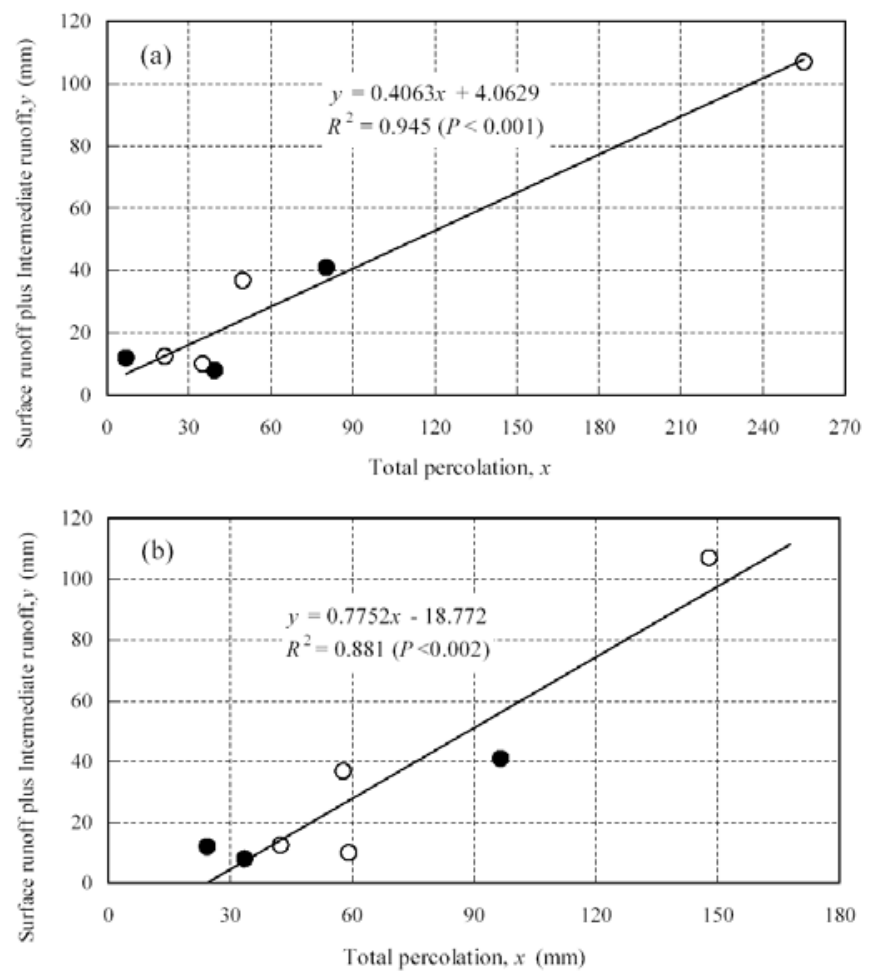

Fig. 12. Relations between total percolation and summed runoff height for the runoff events in the summer season (black circles) and snowmelt season (white circles). (a) forest (b) grassland 
Fig. 12 shows relations between the runoff height and the total percolation at $38 \mathrm{~cm}$ depth of (a) site A (forest) and (b) site B (grassland). There is definitely the linear relationship with $R^{2}$ $=0.945(P<0.001)$ or $R^{2}=0.881(P<0.002)$ between the total percolation and the runoff height at both forest and grassland. At forest, the total percolation is about 2.5 times as large as the runoff heights. The trees, especially the needleleaf trees, tend to hide the ground over the year. Hence, too large the percolation is probably due to the overestimate of the infiltration, $q_{0, t_{1}-t_{2}}$, at the ground surface of site A, since the snow-covered area is relatively small in forest. At grassland (site B), the relationship is relatively close to the one-to-one correspondence. The infiltration given is thus probably reasonable, and the effect of the space between the access tube and the surround soil layer, if any, is judged to be low for the percolation amount. The characteristics of soil moisture variations would be common to grassland and field, as shown by the similar hydraulic conductivity in Table 1 . The linear relationship thus suggests that the surface runoff and intermediate runoff extracted by the tank model are produced by the percolation and subsequent subsurface flow at depths of more than $38 \mathrm{~cm}$. According to the runoff separation by $\delta{ }^{18} \mathrm{O}$ and $\delta \mathrm{D}$ (Yamaguchi, 2011), in the Saromabetsu river basin, the intermediate runoff may occur as a runoff from the perched groundwater zone at depths of less than $10 \mathrm{~m}$. Hence, it is supposed that the modeled surface runoff and intermediate runoff corresponds to the shallow macropore flow and the relatively deep subsurface flow through the perched-groundwater zone, respectively.

\section{Conclusions and future works}

The soil moisture monitoring by the $4 \mathrm{CH}$ moisture profilers showed that, common to the summer and snowmelt seasons, the unsaturated percolation could occur in the porous surface layers at $0-28 \mathrm{~cm}$ depth of forest and at $0-8 \mathrm{~cm}$ depth of grassland. The percolation at $38 \mathrm{~cm}$ depth of forest and grassland was calculated for the rainfall and snowmelt events. In many cases, the percolation was larger at forest than at grassland, especially during the relatively large runoffs. Meanwhile, the simulations by the tank model were carried out for river discharge in the summer and snowmelt seasons. The simulated results were agreeable to the observed ones with the high correlation. The total percolation at $38 \mathrm{~cm}$ depth of forest and grassland during the rainfall and snowmelt events were compared with runoff heights from the surface and intermediate runoffs separated by the simulations. There was definitely the linear relationship between the total percolation and runoff heights. This suggests that the surface and intermediate runoffs obtained by the runoff analysis occur actually as the percolation and subsequent subsurface flow below the soil surface layer.

In this study, it is supposed that the one-point measurements at forest and grassland represents the soil moisture conditions of the soil surface layer all over the river basin. In order to better understand the dynamics of soil water behaviors to produce river runoffs, the information on the distribution and its temporal variability of soil moisture in the $\mathrm{B}$ and $\mathrm{C}$ soil layers on the basin slope and in the riparian zone is needed. Also, in the snowmelt season, the soil moisture condition could change between the north-facing and the south-facing slopes, since a temporal change of snow cover or snow depth is different between the slopes. Thus, the monitoring at a few points at each of forest and farmland by considering the slope direction is necessary. In addition, the infiltration and snow-covered conditions on the forest floor should be observed in the future. 


\section{Acknowledgements}

We are indebted to many local people, especially, Messrs. Yano, Aoki, Kawamura, Nagase and Kan-no for their kind supply of the land and accommodation for field observations. We would like to express special thanks to the Abashiri District Public Works Management Office, the Abashiri Meteorological Observatory and the Geospatial Information Authority of Japan for their welcome data supply.

\section{References}

Aubert, D., Loumagne, C., and L. Oudin (2003): Sequential assimilation of soil moisture and streamflow data in a conceptual rainfall runoff model. Journal of Hydrology, 280, 145-161.

Braun, L. N., and Renner, C. B. (1992): Applications of a conceptual runoff model in different physiographic regions of Switzerland. Hydrological Sciences Journal, 73, 217-231.

Calvo-Cases, A., Boix-Fayos, C., and Imeson, A. C. (2003): Runoff generation, sediment movement and soil water behaviour on calcareous (limestone) slopes of some Mediterranean environments in southeast Spain. Geomorphology, 50, 269-291.

Dingman, S. L. (2002): Physical Hydrology. Prentice Hall, New Jersey, 646pp.

Dunne, T. and Leopold, L. B. (1978): Water in Environmental Planning. Freeman and Co., San Francisco. CA, 818pp.

Gautama, M. R., Watanabe, K., and Saegusa, H. (2000): Runoff analysis in humid forest catchment with artificial neural network. Journal of Hydrology, 235, 117-136.

Grayson, R. B., Western, A. W., and Chiew, F. H. S. (1997): Preferred states in spatial soil moisture patterns: Local and nonlocal controls. Water Resources Research, 33, 2897-2908.

Hall, D. K., Riggs, G. R., and Salomonson, V. V. (2006): MODIS/Terra Snow Cover 8-day L3 Global 500m Grid V005. National Snow and Ice Center, Boulder, Colorado, U.S.A.

Hannah, D. M. and Gurnell, A. M. (2001): A conceptual, linear reservoir runoff model to investigate melt season changes in cirque glacier hydrology. Journal of Hydrology, 246, 123-141.

Harms, T. E. and Chanasyk, D. S. (1998): Variability of snowmelt runoff and soil moisture recharge. Nordic Hydrology, 29 (3), 179-198.

Hollander, H. M., Blume, T., Bormann, H., Buytaert, W., Chirico, G. B., Exbrayat, J.-F., Gustafsson, D., Holzel, H., Kraft, P., Stamm, C., Stoll, S., Bloschl, G., and Fluhler, H. (2009): Comparative predictions of discharge from an artificial catchment (Chicken Creek) using sparse data. Hydrol. Earth Syst. Sci., 13, 2069-2094.

Kayane, I. (1980): Hydrology. Daimyo-do, Co., 272pp.

Kido, D., Chikita, K. A., and Hirayama, K. (2007): Subglacial drainage system changes of the Gulkana Glacier, Alaska: discharge and sediment load observations and modelling. Hydrological Processes, 21, 399-410.

Martinez, C., Hancock, G. R.. Kalma, J. D., and Wells, T. (2008): Spatio-temporal distribution of near-surface and root zone soil moisture at the catchment scale. Hydrol. Process. 22, 2699-2714.

Meyles, E., Williams, A., Ternan, L., and Dowd, J. (2003): Runoff generation in relation to soil moisture patterns in a small Dartmoor catchment, Southwest England. Hydrological Processes, 17, 251-264.

Nakano, M., Miyazaki, T., Shiozawa, A., and Nishimura, T. (1995): Measurements for Physical Environments of Soil. Tokyo University Press, 237pp. 
Nash, J. E. and Sutcliffe, J. V. (1970): River flow forecasting through conceptual models part I - A discussion of principles. Journal of Hydrology, 10 (3), 282-290.

Nielsen, S. A. and Hansen, E. (1973): Numerical simulation of the rainfall-runoff processes on a daily basis. Nordic Hydrology, 4, 171-190.

Penna, D. (2008): Soil moisture distribution and runoff response at the hillslope scale: Experimental analysis in an alpine environment. $\mathrm{PhD}$ thesis, Universita Degli Studi di Padova, 127pp.

Penna, D., Meerveld, H. J. T., Gobbi, A., Borga, M., and Fontana, G. D. (2011): The influence of soil moisture on threshold runoff generation processes in an alpine headwater catchment. Hydrol. Earth Syst. Sci., 15, 689-702.

Rango, A. and Martinec, J. (1995): Revising the degree-day method for snowmelt computations. Jour. Amer. Water Resour. Assoc., 31, 657-669.

Sugawara, M. (1972): A method for runoff analysis. Kyoritsu Shuppan Press, Tokyo. van Asch, T. W. J., van Dijck, S. J. E., and M. R. Hendriks, M. R. (2001): The role of overland flow and subsurface flow on the spatial distribution of soil moisture in the topsoil. Hydrological Processes, 15, 2325-2340.

Wada, T., Chikita, K. A., Kudo, I., Kido, D., and Narita, Y. (2007): Glacial effects on discharge, sediment load and water chemistry from a subarctic river basin. Journal of Japanese Association of Hydrological Sciences, 37, 103-113.

Yagisawa, K. (2008): Basin slope hydrology based on the different land cover. MS thesis, Hokkaido University, 49pp.

Yamaguchi, T. (2011): The nutrient load from a drainage basin of different land cover. MS thesis, Hokkaido University, 37pp.

(原稿受付：2011年 1 月 1 日)

(原稿受理：2011年 6 月25日)

この論文に対する「討論」を2012年 8 月31日ま で受け付けます。 


\section{土袞水の挙動特性と河川流出への役割： 北海道・佐呂間別川流域}

モハメド T. イスラム*1・知北 和久*2 ・和田 知之*2 ・ 山口 拓真 ${ }^{* 1}$

要 旨

北海道・佐呂間別川（流域面積 $259.3 \mathrm{~km}^{2}$ ） の流域斜面で，2008 年 6 月〜 2009 年 5 月の期間，土畩水分量をモニタリングし，森林と牧草地における降雨・融雪 に伴う土壤水の挙動を調べた。同流域の土地被覆は，主に森林（占有率 $75.2 \%$ ） と農地（同 $21.5 \%$ ）で，測定点での土壌構造は，森林・牧草地共に，透水性のよ い有機層 ( $\mathrm{A}$ 層，平均厚さ $0.3 \mathrm{~m}$ 未満）と透水性の悪い有機 / 無機層（B 層，平 均厚さ約 $10 \mathrm{~m}$ 以上） からなる。用いた土壌水分計は 4 チャンネルのプロファイ 儿土潩水分計で, $8 \mathrm{~cm}, 18 \mathrm{~cm}, 28 \mathrm{~cm}, 38 \mathrm{~cm}$ 深度で 20 分間隔で体積含水率 $\left(\mathrm{cm}^{3} /\right.$ $\left.\mathrm{cm}^{3}\right)$ が求められた。結果として，森林斜面では 8-28 cm 深でイベント後の 2 〜 3 日間は貯水状態にあり，その後は速やかに排水され，イベント前の土畩水分レ ベルに戻ることがわかった。一方，牧草地斜面では， $8 \mathrm{~cm}$ 深でイベント後の排 水は速やかだが，さらに深い層では排水はほとんど行われなかった。また，20 $\mathrm{mm} / \mathrm{h}$ 以上の降雨では，森林斜面の $38 \mathrm{~cm}$ 深と牧草地斜面の $8 \mathrm{~cm}$ 以深で飽和状 態となった。以上から，イベント時は透水性のよい層の下で浸透流がさかんであ ることがわかった。ここでは，得られた土畩水分データを用いて降雨と融雪の各 イベントごとの $38 \mathrm{~cm}$ 深での降下浸透量を求めた。他方，タンクモデルによつ て佐吕間別川に対する流出解析を実施し，結果として，降雨・融雪イベント時に 応答の早い直接流出 (表面流出 + 中間流出) が $70 \%$ 以上を占めることがわかった。 この直接流出量と先に求めた降下浸透量を比較すると，全体として明瞭な直線関 係が認められた。このことより，流出解析で得られる直接流出は，実際には土壤 表層下の浸透流として発生することが示唆された。

キーワード:土畩水分，降雨流出，融雪流出，浸透流，タンクモデル，表面流出， 中間流出

* 1 北海道大学大学院理学院自然史科学専攻

* 2 北海道大学大学院理学研究院自然史科学部門 